УДК 902/904

https://doi.org/10.24852/2587-6112.2021.4.183.196

\title{
МУСУЛЬМАНСКИЕ КАМЕННЫЕ НАДГРОБИЯ ХІV ВЕКА ИЗ ЗОЛОТООРДЫНСКОГО АЗАКА
}

\author{
(C) 2021 г. А.П. Минаев, Н.И. Юдин
}

Целью работы является свести воедино все найденные в ходе раскопок золотоордынского Азака каменные мусульманские надгробия XIV века. На настоящее время изучению городских и сельских некрополей золотоордынских городов, в том числе и Азака, посвящено большое количество публикаций. В работах, помимо описания погребального обряда, много сказано и надмогильных сооружениях. Однако основное внимание в исследованиях уделено описанию эпиграфических надписей на надгробиях. Архитектурное оформление надгробных памятников часто остается вне поля зрения исследователей. В данной работе уделено внимание как эпиграфиям, так и стилистическим особенностям оформления надгробных стел. Нами отмечено, что в оформлении надгробий из Азака отчетливо прослеживается влияние традиций малоазийского региона в эпоху сельджуков. Но в отличие от находок из Турции, надгробия Азака и крымских городов менее орнаментированы и схематично оформлены. Исследование каменных памятников, в том числе надгробий, позволяет выявить культурные, экономические, религиозные процессы, протекавшие в Азаке, а также определить истоки тех или иных художественных традиций разных регионов Золотой Орды.

Ключевые слова: археология, Золотая Орда, Азак, эпиграфика, надгробие, сульс, рельеф, арка, лампада, свеча, михраб.

\section{MUSLIM STONE GRAVESTONES OF THE $14^{\mathrm{TH}}$ CENTURY FROM THE GOLDEN HORDE CITY OF AZAK}

\section{A. P. Minaev, N. I. Iudin}

The purpose of the work is to combine all stone Muslim gravestones of the $14^{\text {th }}$ century found during the excavations of the Golden Horde city of Azak. A significant number of publications covers studies of urban and rural necropolises of the Golden Horde cities, including Azak. The publications, in addition to the description of the funerary rite, contain details of the graveside structures. However, the studies are mainly focused on the description of epigraphic inscriptions on gravestones. Their architectural design often falls out of the researchers' field of interest. In this work, attention is paid to both the epigraphy and the stylistic features of gravestone design. As noted by the authors, the design of Azak gravestones clearly traces the influence of Asia Minor region's traditions of the Seljuk period. But unlike the finds from Turkey, the gravestones of Azak and the Crimean cities are less ornamented and schematically decorated. The study of stone monuments, including gravestones, allowes to identify the cultural, economic and religious processes that took place in Azak, as well as to determine the origins of certain artistic traditions of different regions of the Golden Horde.

Keywords: archaeology, Golden Horde, Azak, epigraphics, gravestone, thuluth, relief, arch, lantern, candle, mihrab.

Среди большого количества археологического материала, найденного в процессе раскопок золотоордынского Азака, особое место занимают надмогильные сооружения из городских некрополей. Они представляют огромный интерес для изучения духовной жизни горожан, позволяют выявить особенности религиозный воззрений, обычаев и традиций, миграционных процессов, протекавших в Золотой Орде. Азак, являясь крупнейшим торговым и административным центром Нижнего Подонья, имел обширные хозяйственные и культурные связи, как с другими золотоордынскими центрами, так и с отдалёнными регионами Евразии (Испания, Италия, Центральная Азия, Китай).

Истории изучения лапидарных памятников Золотой Орды посвящено большое количество исследований (Якобсон, 1973; Мухаметшин, 2008; Айбабина, 2001; Усеинов, 2019, с. 89-95). В работах были выделены региональные особенности погребальных комплексов для регионов Золотой Орды. На территории Волжской Болгарии было выявлено более 400 целых или фрагментированных каменных надгробий и выделено 4 региональных округа, каждый из которых имел художественные особенности (Мухаметшин, 2008, с. 23-24). Болгарские надгробия имеют четко выраженную форму с определенным каноническим текстом и широким использованием растительного орнамента. Камни имели форму 
плоской вертикальной стелы с прямоугольными, треугольными или полукруглыми навершиями. На лицевой стороне стелы рельефно выделена арка самой разнообразной формы (стрельчатая, полукруглая или килевидная), наносилась богатая растительная орнаментация с использованием розеток, плетенок, бордюров. Стелы устанавливались у изголовья погребенного, лицевой стороной на восток. Нижняя часть камня, вкапываемая в землю, не обрабатывалась. Эпитафии наносились рельефным или врезным почерком куфи, насх или сульс. Отличительными особенностями булгарских надгробий являются обязательное наличие коранической формулы в верхней части стелы, ниже идут слова, связанные с обрядом захоронения, далее идут имя, титул, родословная погребенного и благожелательная формула. Как обязательный элемент, на большей части надгробий присутствует кораническая формула «Он живой»/ ه . Широкое распространение получило нанесение в тимпане розеток самой разнообразной формы. На настоящий момент болгарские надгробные памятники являются наиболее изученными, существуют работы с подробной их классификацией и датировкой (Мухаметшин, 2008).

В золотоордынских могильниках Нижнего Поволжья большая часть захоронений не имеет надмогильных сооружений. Только небольшое количество погребений (около 13\%) имели надгробия (Васильев, 2007, с. 72). Связано это с отсутствием в низовьях Волги местного камня, а небольшое количество обнаруженных надгробных камней, по всей видимости, были привезены из других регионов Золотой Орды (Пигарев, Тимофеев, 2018, с. 70). В Астраханском музее хранятся два каменных надгробия - одно из них найдено на городище Хаджи-Тархан, другое на городище Мошаик (Пигарёв, Тимофеев, с. 68-71). Обе стелы плоские, вертикальные, плита из Хаджи-Тархана с плоским навершием, вторая плита из Мошаика - с пятилопастной аркой и треугольным навершием. Эпиграфические надписи выполнены арабскими буквами почерком рельефным сульс с помощью выборки фона в низком рельефе. Текст на камне из Хаджи-Тархана нанесен в основном поле и по периметру плиты с коранической формулой «Каждый смертен» и годом смерти умершего, на камне из Мошаика сохранилось только имя погребенной. Плита из Хаджи-Тархана имеет прямые аналогии с надмогильными сооружениями из некрополей средневекового Южного
Дагестана XI-XIII вв. (например, из кладбища села Татиль Табасаранского района) (Шихсаидов, 1984, с. 33-39). Плита из Мошаика по внешнему оформлению более близка к старокрымским или маджарским надгробиям. Это подтверждается формой арки - многолопастные навершия, стилизованные под изображение цветка, не встречаются на болгарских и дагестанских надгробиях.

Исследованию погребальных золотоордынских комплексов на территории Северного Кавказа посвящено немало работ (Волков, 2018, с. 38-42; Шихсаидов, 1984). К настоящему времени наиболее изучены надмогильные памятники средневекового Дагестана, исследованиям которых посвящено большое количество работ (Шихсаидов, 1984; Маммаев, 2019, с. 704-722). Внешне дагестанские надгробия представляют собой плоские прямоугольные или сужающиеся к низу стелы с плоским, закругленным или треугольным верхом. Многие памятники богато орнаментированы, с преобладанием растительных мотивов в виде пальметт, побегов и трилистников, на некоторых памятниках нанесены стилизованные антропоморфные фигуры. Большинство надгробных камней содержат кораническую формулу, имя и дату смерти умершего, титул и родословную, а также благожелательную формулу («Да простит его Аллах» и др.).

Найденные на территории золотоордынского Маджара надгробия ближе к крымским и малоазийским памятникам, чем к дагестанским камням. Маджарские стелы, как правило, плоские прямоугольные, без сужения к низу, с пяти- или семилопастной аркой. В арках могла изображаться пальметта с расходящимися растительными побегами. Преобладают эпиграфические надписи, выполненные рельефным сульсом, в то время как на камнях из горного и степного Дагестана были широко распространены шрифты сульс, насх и куфи (в том числе процветший). К сожалению, надмогильные памятники Маджара исследованы значительно меньше, чем из поселений Дагестана. Связано это с меньшей исследованностью маджарского некрополя XIII-XIV вв., а также с тем, что надгробия с территории городских и сельских средневековых некрополей Дагестана сохранились значительно лучше.

Мусульманские эпиграфические памятники Крыма упоминали в своих работах исследователи с конца XVIII века, отмечая их варварское разграбление и уничтожение (Усеинов, 2019, с. 87). В 1925-1927 гг. в Старом Крыму 
проводилась Экспедиция по изучению татарской культуры в Крыму под руководством И.Н. Бороздина. В ходе экспедиции было собрано большое количество (более 200) лапидарных памятников, относящихся ко времени Золотой Орды и раннего Крымского ханства. Большая часть собранного материала была утрачена во время репрессий 1930-1940-х гг. и в период Великой Отечественной войны, а исследование крымско-татарской материальной культуры надолго приостановлено. Вновь интерес к истории средневековой татарской культуры появился с конца 1970-х гг., когда была образована Старокрымская археологическая экспедиция Государственного Эрмитажа (под руководством М.Г. Крамаровского), продолжающаяся и в наши дни. В настоящий момент экспедицией выявлено около 200 целых или фрагментированных лапидарных памятников, большая часть из которых содержит надписи. Всего за время проведения экспедиций И.Н. Бороздина и М.Г. Крамаровского было собрано более 380 каменных памятников, из которых около 280 камней составляют надмогильные конструкции (Усеинов, 2019, с. 88).

В ходе экспедиций 1920-х гг. в Крыму местным этнографом и археологом О.-Н. Акчокраклы было выделено 2 основных типа надгробных стел. Первый тип - это плоские камни со стрельчатым или килевидным навершием, второй - круглые или восьмигранные тумбы с фигурным навершием. По утверждению автора, первый тип памятников принадлежал исключительно женщинам, второй тип - только мужчинам (Акчокраклы, 1929, с. 152-153). М.А. Усеинов в своей исследовательской работе по изучению мусульманских эпиграфических памятников Старого Крыма выделил пять основных типов надгробий восьмигранные или цилиндрические тумбы, плоские стелы со стрельчатым верхом, саркофаги (двурогие или безрогие) и составные (Усеинов, 2019, с. 90). Надписи на памятниках выполнены на арабском языке почерком рельефный сульс золотоордынской трактовки, небольшое количество надписей выполнено на чагатайском наречии. Внешнее оформление крымских надгробий очень многообразно. Наиболее высокохудожественные образцы происходят из крупных городских центров Солхата, Чуфут-Кале, Салачика, Бахчи-Сарая. На периферийных степных и горных золотоордынских могильниках встречены довольно грубые изделия, большей частью без орнамента и эпиграфий. Наибольший интерес представляют каменные надгробия из Солхата - столичного центра золотоордынского Крыма, плоские стелы в основном прямоугольной формы, с полукруглой или килевидной аркой. Особую разновидность представляют стелы с пяти- или семилепестковой вершиной (имитация розетки). На большей части надгробий орнамент выполнен в низком рельефе с выборкой фона. Орнамент предельно схематичен, с проработкой по контуру. Распространенные мотивы орнамента - розетки, растительные побеги, пальметты, шестиконечные звезды, сложные геометрические плетенки, сельджукская цепь («узел счастья»). Разнообразие форм и орнаментации зависело не только от мусульманских канонов, но и от художественных традиций местных мастеров-камнерезов и вкусов самих заказчиков (Айбабина, 2016, c. 532). Одним из наиболее распространенных орнаментальных элементов на крымских каменных надгробиях является стилизованное изображение свечи или лампы. Изображение лампады или свечей нанесено в верхней половине плоской стелы или тумбы, на большинстве надгробий без выборки фона, лишь на некоторых богато оформленных камнях изображения выполнены в низком рельефе. Лампады с шаровидным или вытянутым туловом, коническими горлом и поддоном подвешены на двух цепях, крепящихся на пальметте. Иногда на тулове лампы могла наноситься цветочная розетка. На некоторых камнях по бокам от лампы симметрично располагались две высокие свечи на конических или биконических подсвечниках. Иногда на центральной части надгробия вместо лампады наносилось изображение высокой горящей свечи на высоком подсвечнике. Изображение свечей в подсвечниках и подвешенных на цепочках горящих лампадах на каменных надгробиях широко распространено на сельджукских лапидарных памятниках Малой Азии (Усеинов, 2019, с. 93). Согласно представлениям сельджукского культа, зажженная лампада символизировала свет веры, данный Всевышним, а две свечи в подсвечниках - это свет знаний Корна и Сунны пророка Мухаммеда (Усеинов, 2019, с. 93). Сельджукское влияние на каменную резьбу золотоордынского Крыма уже неоднократно отмечали исследователи (Айбабина, 2016, с. 512), что выражено не только в форме надгробий, но и в орнаментальных мотивах. Аналогии крымским надмогильным памятникам встречены в городах Малой Азии (Ахлат, Сивас, Кастамону, Изник и др.) (Усенинов, 2019, с. 93). Сельджукские традиции оформления надгробий были пере- 
няты мастерами Крыма в процессе их расселения в Юго-Восточном Крыму со второй половины XIII века. Отличие от сельджукских образцов состояло лишь в упрощении орнаментации и в эпиграфическом оформлении надгробий. Лампы на анатолийских образцах богато орнаментированы, горло и поддон часто украшены пышным растительным и сложным геометрическим орнаментом, на тулове лампы могла помещаться кораническая формула. Надписи на сельджукских лапидарных памятниках соблюдают большинство канонов восточной каллиграфии, все элементы букв присутствуют, включая такие специфические как фэтха и кэсра. Крымские мастера, перенявшие традиции от сельджукских камнерезов, значительно упростили стилистику оформления надгробий. Сельджукское влияние на каменную монументальную архитектуру продолжалось до 30-х гг. XV века, когда ослабло влияние Солхата как золотоордынского столичного центра.

Археологическое исследование золотоордынского Азака началось еще в 1870 году, когда П.И. Хицунов провел первые археологические раскопки на территории памятника. Им же были проведены раскопки ограбленного кургана на восточной окраине Азова, где была выявлена «небольшая тщательно отесанная, по всей вероятности, надгробная, плита из твердого песчаника, украшенная изсеченными на ней изображениями, с одной стороны, звезды среди вписанного в круг шестиугольника, а с другой стороны - стоящего на пьедестале обелиска» (Волков, 2008, с. 495). Судя по такому краткому описанию, плита являлась частью золотоордынского надгробия. На это косвенно указывает шестиугольник со звездой, вписанный в круг, который, по всей вероятности, являлся гексаграммой («звездой Давида»), изображение которой часто наносилось на фасады порталов и надгробные стелы. Изображение гексаграммы распространено в символике многих народов Востока и связано с обращением к Богу (Айбабина, 2016, с. 530). Стоящий на пьедестале обелиск мог нести изображение свечи на высоком подсвечнике - мотив, часто распространенный на надгробных стелах в Крыму, Северном Кавказе и Малой Азии. Исходя из сравнений с другими аналогичными лапидарными памятниками Крыма и Малой Азии, можно сказать, что каменная плита являлась самой первой находкой каменного золотоордынского надгробия XIV века, найденная в Азове. К сожалению, данное надгробие до наших дней не сохра- нилось. Не удалось пока установить и точное местоположение исследованного в 1870 году кургана.

Со времени проведения П.И. Хицуновым археологических раскопок в конце XIX века каких-либо полноценных археологических исследований могильников на территории Азака не проводилось. Исследование золотоордынского Азака вплоть до конца 1970-х гг. носило эпизодический характер, когда во время проведения земляных работ в строительных котлованах доследовались закрытые комплексы XIV века (хозяйственные ямы, жилые и производственные сооружения). Полноценное изучение могильников Азака относится к началу 1980-х гг. Кэтому же времени относится и выявление каменных золотоордынских надгробий. На данный момент найдено 13 фрагментов каменный надгробий (с учетом утерянного надгробия, найденного в 1870 г.) (рис. 1). Почти все надгробия изготовлены из местного материала (песчаник или ракушечник). Материалом для изготовлений надгробий могли служить вторично использованные строительные блоки. Некоторые надгробия искусно вытесаны и орнаментированы, другие же выполнены предельно схематично. Орнаментальные мотивы и эпиграфика, встреченные на камнях, ведут свои истоки из мастерских камнерезов столичных и периферийных центров ордынского Крыма. Форма камней, оформление арки в виде многолопастной розетки, изображения свечей и лампад указывают на сильное влияние сельджукской традиции, которую к XIV веку переняли крымские мастера. На найденных азакских надгробиях присутствует особая стилистика нанесения эпиграфических надписей, которая характерна только для Крыма, а именно (за одним исключением) отсутствие обязательной для болгарских и дагестанских надгробий коранической формулы («Он живой...» и др.) в начале текста. Текст на сохранившихся фрагментах начинается с указания даты смерти погребенного. Текст на камнях выполнен почерком сульс, который получил почти полное распространение на могильных стелах только в Крымском улусе.

В 1984 году в Азовский музей была передана часть надгробной плиты, найденная местными жителями при проведении земляных работ на участке по ул. Севастопольская, 84 (Волков, 2018, с. 379-384). Фрагмент надгробия был выявлен в могильнике, расположенном на западной окраинной части золотоордынского Азака (№ 35 по А.Н. Масловскому) 


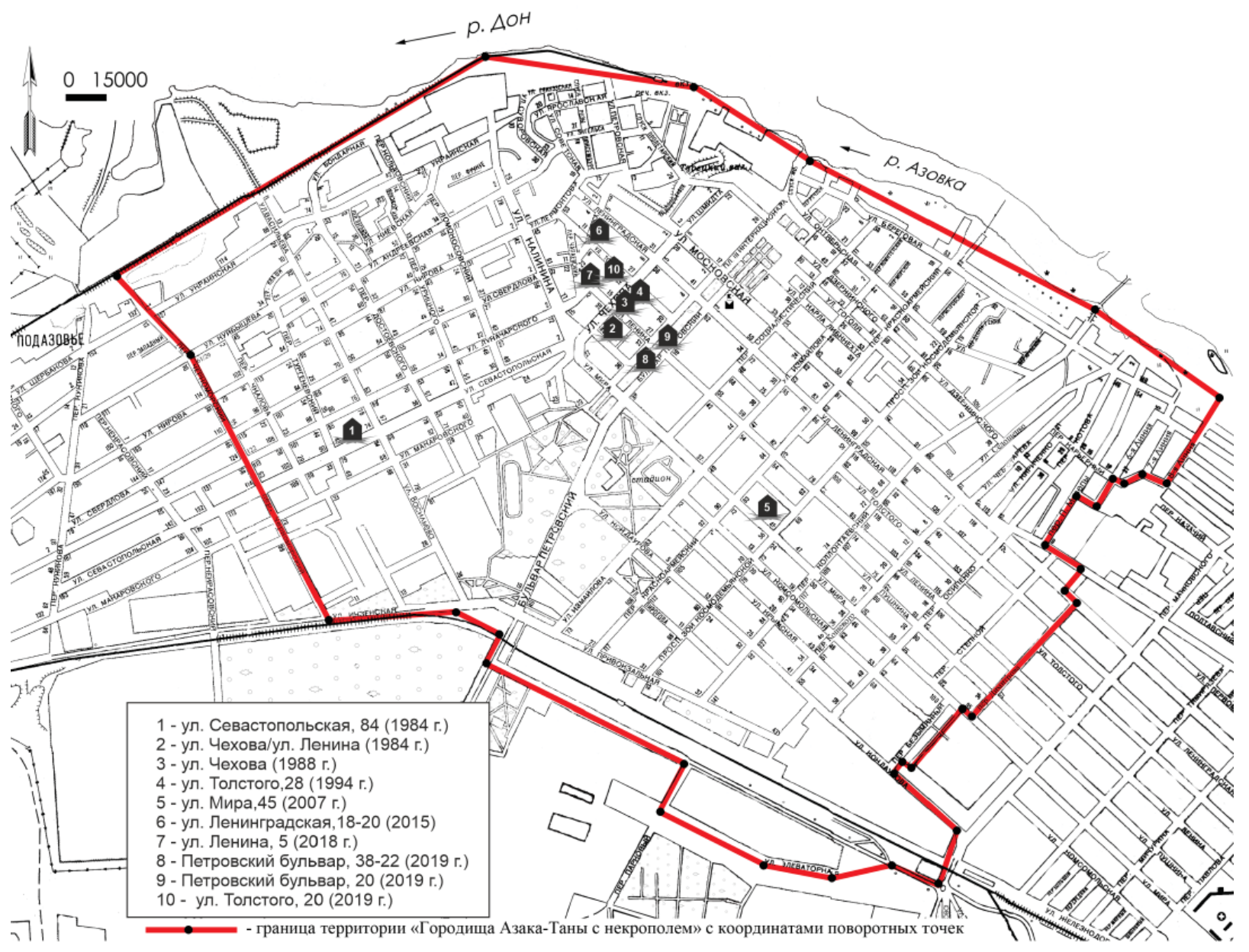

Рис. 1. Карта Азова с местоположением раскопов с находками каменных надгробий

Fig. 1. Map of Azov with the location of the excavations with gravestones finds

(Масловский, 2018, с. 348). Плоская вертикальная стела (рис. 5: 3) с треугольной вершиной, размерами $21 \times 14,7 \times 3,5$ см, изготовлена из низкокачественного мрамора, со следами воздействия огня, нижняя часть обломана. На обеих сторонах плиты нанесен растительный орнамент и эпиграфические надписи. Растительный орнамент выполнен в верхней части надгробия, на треугольных вершинах, в виде небольших пальметт - на одной стороне трехлепестковой, на противоположной - пятилепестковой, внутри которых нанесены каплевидные прорези. От пальметт в нижней части расходятся побеги с раздваивающимися краями. Орнамент выполнен с помощью выборки фона в низком рельефе. Основное поле плиты с каждой стороны разбито на два прямоугольника, внутри которых на обеих сторонах помещены строки арабскими буквами почерком насх. Надпись в переводе гласит следующее: «Написано в месяце джумада первом года семьдесят шестого и семисотого...» (в переводе И.В. Волкова). Дата на надгробии соответствует 8 октября - 7 ноября 1374 г. Небольшой размер надгробия может указывать на то, что оно предназначалось умершему ребенку, а не взрослому человеку. Такая практика была широко распространена на средневековых могильниках горного Кавказа (в частности, Дагестана), где детские надгробия аналогичны погребениям взрослых или старых людей (Маммаев, 2019, с. 706). Детские надгробия из Дагестана могли быть пышно украшены растительным орнаментом, с помещением коранической формулы, имени и даты смерти умершего.

В 1988 году при проведении спасательных археологических раскопок в центральной части Азака по ул. Ленина в одном из погребений был найден фрагмент каменного надгробия (рис. 1) (Волков, 2018, с. 379). Раскоп располагался в западной части центрального городского могильника XIV в. (№ 3 по А.Н. Масловскому) (Масловский, 2018, с. 322). Надгробие интересно тем, что изготовлено из вторично использованного строительного блока из желто-серого ракушечника, размерами $29,8 \times 21,4 \times 10,5$ см (рис. 2: 1). Стороны блока тщательно обтесаны, нижний край камня обломан. На одной из сторон надгробия в центральной части схематично нанесено изображение горящей лампады с округлым 


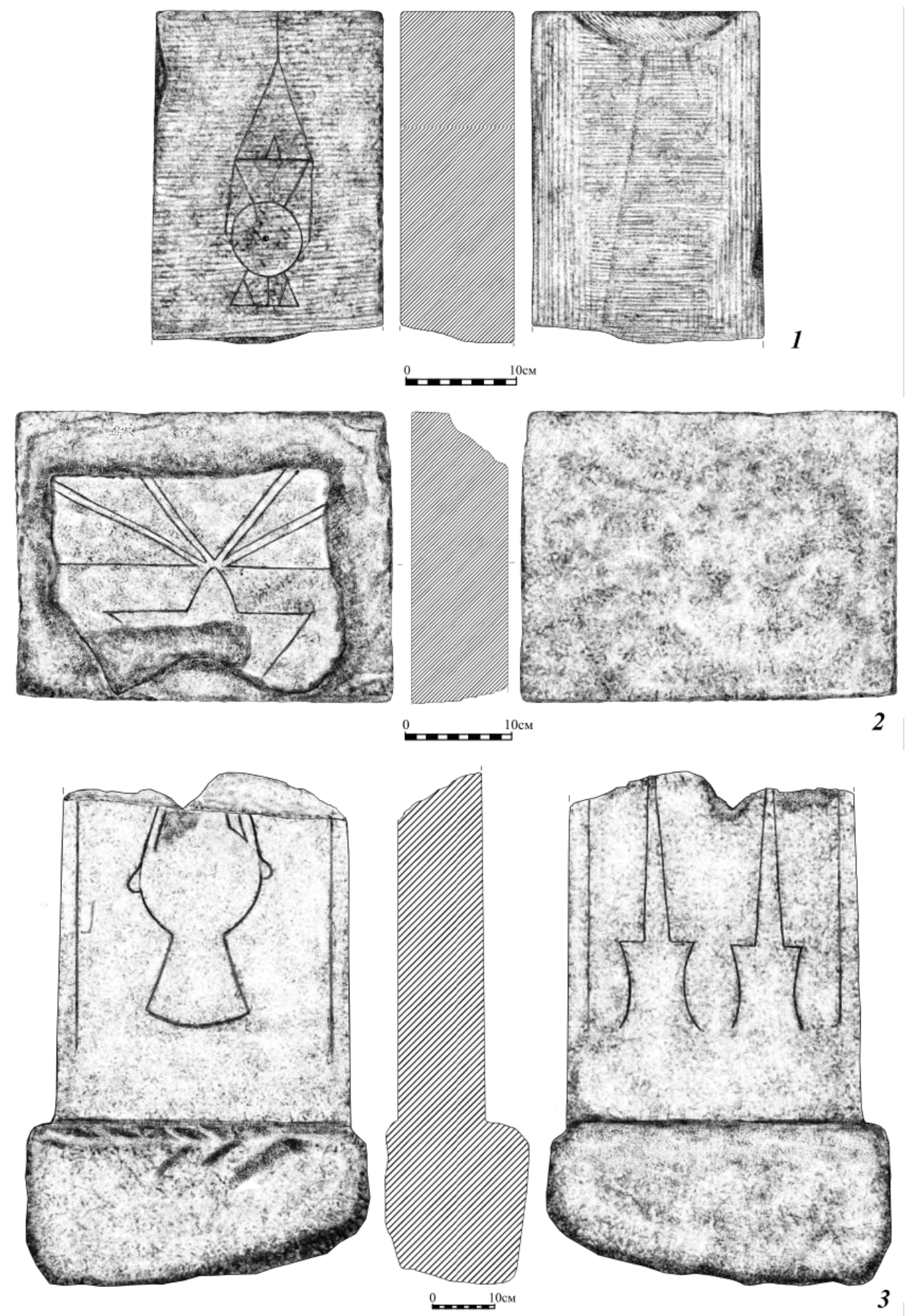

Рис. 2. Каменные надгробия из Азака: 1 - раскоп по ул. Чехова/Ленина (1988 г.), 2 - раскоп по ул. Ленинградская, 18-20/Щорса, 7 (2015 г.), 3 - раскоп по ул. Ленина, 5 (2018 г.).

Fig. 2. Stone-made gravestones from the city of Azak: 1 - excavation on the Chekhova/Lenina st. (1988), 2 - excavation on the Leningradskaya st., 18-20 / Schorsa st., 7 (2015), 3 - excavation on the Lenina st., 5 (2018).

туловом, коническим поддоном и горлом. Лампа подвешена на двух цепях, прикрепленных к центральной части тулова. Лампада помещена в михраб с полукруглой аркой. Оборотная сторона камня не содержит орнамента. Мотив горящей лампады, помещенной в михраб, распространен на городских и сельских могильниках Крыма и Малой Азии и трактуется как свет веры, который дан Всевышним.

На раскопе по ул. Чехова в 1988 году в строительном котловане был найден фрагмент каменного надгробия, изготовленного из желто-серого ракушечника, размерами 42,5×35,0×8,0 см (рис. 3: 1) (Гудименко, Перевозчиков, 1989, с. 14). Исследованный 
участок располагался в восточной окраинной части центрального городского могильника XIV в. (№ 3 по А.Н. Масловскому) (Масловский, 2018, с. 322). Вертикальная стела прямоугольной формы, вершина в форме пятилопастной арки с килевидным навершием (имитация розетки). Орнамент выполнен с помощью выборки фона в низком рельефе. На одной стороне плиты внутри арки нанесена трехлепестковая пальметта с расходящимися в стороны раздваивающимися по краям растительными побегами. Основное поле плиты занимает простой геометрический орнамент в виде ромбовидных фигур, схематично имитирующих шестилепестковые розетки. На оборотной стороне плиты в арке нанесены две шестиконечные гексаграммы, вписанные одна в другую. В верхней части основного поля плиты нанесено изображение «сельджукской цепи» с вписанными внутри шестиугольными фигурами. В центральной части основного поля нанесено изображение двух гексаграмм, вписанных одна в другую. Изображение гексаграммы и «сельджукской цепи» - распространенный мотив орнамента, встречающийся на стелах из могильников Крыма и Анатолии. Орнамент на данном надгробии выполнен предельно схематично, что может указывать на изготовление его не анатолийскими, а крымскими камнерезами.

На раскопе по ул. Толстого, 28, в 1994 году были найдены 3 фрагмента каменного надгробия (Гудименко, 1997, с. 76). Могильник располагался на восточной окраине центрального городского могильника Азака (№ 3 по А.Н. Масловскому) (Масловский, 2018, с. 325). Вертикальная стела прямоугольной в плане формы, размерами $33,7 \times 32,1 \times 9,0 \mathrm{~cm}$, изготовлена из желто-серого ракушечника, с трехлопастной аркой, половина арки и нижняя часть стелы утрачены (рис. 3: 2). На одной стороне плиты нанесено изображение горящей лампады, подвешенной на двух цепях, с коническим горлом и округлым (?) туловом, помещенной в михраб со стрельчатой аркой. Свет лампады изображен тонкими расходящимися от центра горла линиями. Изображение нижней части лампы утрачено. На оборотной стороне плиты нанесена эпиграфия арабскими буквами почерком рельефный сульс, выполненная с помощью выборки фона в низком рельефе. Большая часть текста утрачена, сохранившаяся часть надписи помещена в прямоугольную рамку. По сохранившимся буквам удалось восстановить часть текста: «Он живой...»/ إنه حي ع (в переводе Н.И.
Юдина) и букву $\varepsilon$, вероятно являющуюся началом другого слова. Отметим некоторые любопытные факты, относящиеся к найденному надгробию. Данная начальная кораническая формула как обязательный элемент присутствует на надгробных стелах из Болгара и имеет следующее продолжение: «...который не умирает, все живущее умрет» (Мухаметшин, 2008, с. 26). На крымских и северокавказских надгробиях надпись обычно начинается либо с фразы «Это могила покойного (покойной)...» и далее следует имя, либо с даты смерти умершего. Стилистические особенности оформления данного памятника (форма надгробия, эпиграфика и изображенная на одной из сторон горящая лампада) указывают на то, что надгробие изготовлено крымскими мастерами под влиянием сельджукской традиции.

Еще одно надгробие было найдено в 2007 году на раскопе по ул. Мира, 45. Исследованный участок занимал один из городских могильников в южной части Азака (№ 13 по А.Н. Масловскому) (Масловский, 2018, c. 338). Фрагмент надгробия, найденный в хозяйственной яме № 3 XIV в., размерами $20,1 \times 21,3 \times 10,1$ см, изготовлен из светложелтого ракушечника (Масловский, 2010, с. 198). Большая часть камня утрачена, сохранился только край надгробия с ровно обтесанной гранью (рис. 3: 3). Обе стороны надгробия по внешнему краю оформлены в виде невысокого бордюра, внутреннее поле разделено бордюром на три части (возможно и более). Орнаментирована только одна из сторон в виде эпиграфической надписи арабскими буквами почерком рельефным сульс, выполненной с помощью выборки фона в низком рельефе. Большая часть надписи, к сожалению, утрачена, удалось восстановить только небольшую ее часть в одном из прямоугольников - это цифры 10 и 5 (в переводе Н.И. Юдина). По всей вероятности, сохранившиеся цифры могут указывать на дату смерти погребенного.

В 2015 году на раскопе по ул. Ленинградская, 18-20/Щорса, 7, при исследовании могильника XVII-XVIII вв. было найдено два каменных надгробия (Кравченко, 2018, с. 125). Одно из них датируется периодом турецкого Азова (XVII-XVIII вв.), другое же относится ко времени существования золотоордынского Азака. Камень прямоугольной формы размерами $35,5 \times 27,6 \times 9,1 \mathrm{~cm}$, с плоской вершиной, изготовлен из светло-желтого ракушечника (рис. 2: 2). Надгробие, вероятно, изготовлено 

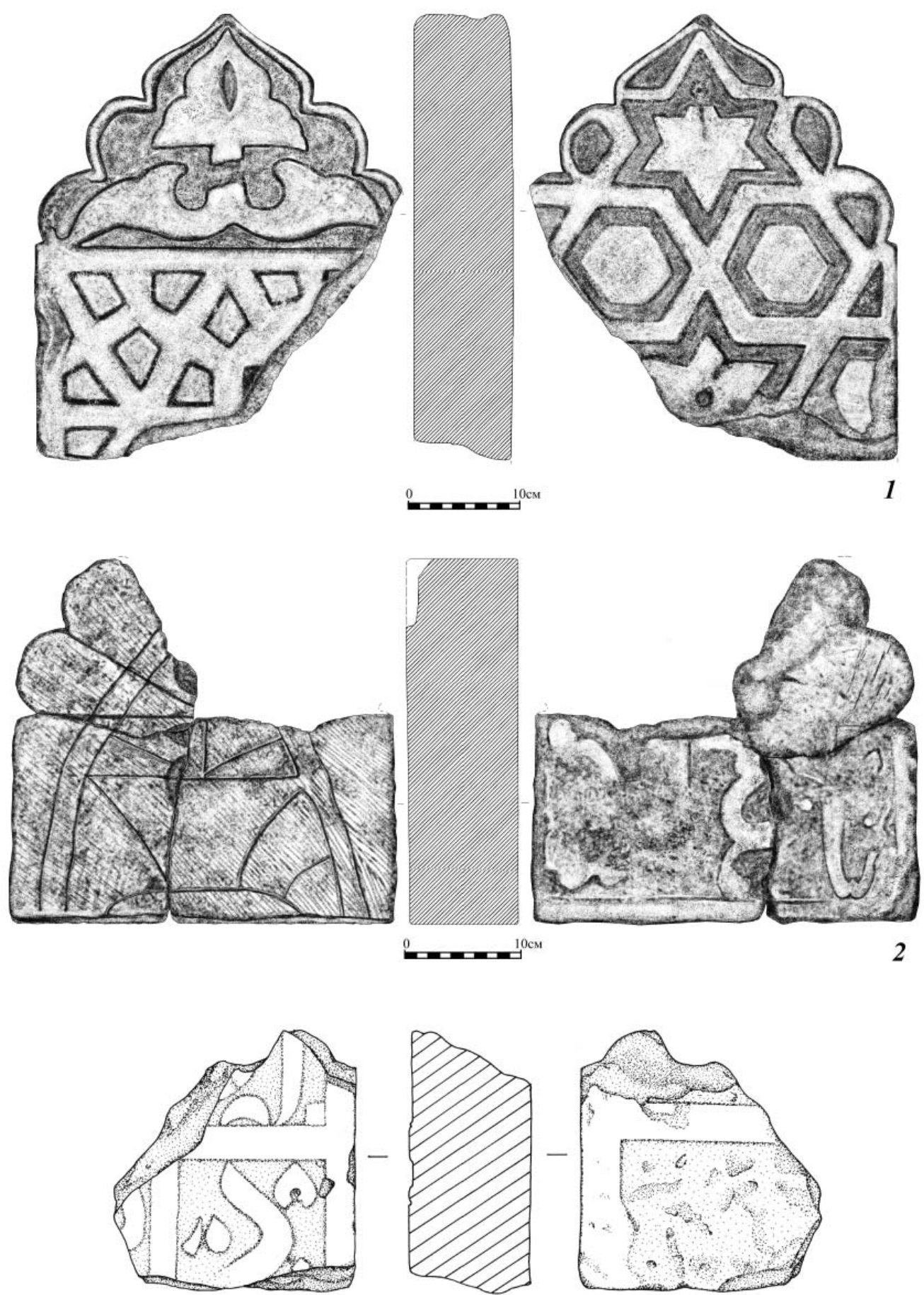

10.0.

Рис. 3. Каменные надгробия из Азака: 1 - раскоп по ул. Чехова (1988 г.), 2 - раскоп по ул. Толстого, 28 (1994 г.), 3 - раскоп по ул. Мира, 45A (2007 г.).

Fig. 3. Stone-made gravestones from the city of Azak: 1 - excavation on the Chekhova st., (1988), 2 - excavation on the Tolstogo st., 28 (1994), 3 - excavation g on the Mira st., 45A (2007).

из вторично использованного строительного каменного блока, грани сильно повреждены, однако можно проследить, что плита имела ступенчатую форму. Обе стороны камня тщательно обтесаны. Орнамент нанесен только на одну сторону плиты в виде схематичного изображения горящей лампады, выполненного тонкими врезными линиями. Сохранилась только верхняя часть лампады. Горло лампы конической формы, от пламени треугольной в плане формы расходятся в разные стороны лучи в виде тонких линий. Лучи лампы вырезаны, вероятно, с помощью двузубого резца. Надгробия с изображением горящей лампады ранее встречались на городских могильниках Азака. Этот камень интересен тем, что орнамент на нем нанесен предельно схематично, без детальной проработки. На стеле 
отсутствуют цепь, к которой была подвешена лампа, и михраб, в который она помещалась.

В 2018 году на раскопе по ул. Ленина, 5, было найдено 2 фрагмента каменных надгробий XIV в. Исследованный участок занимал северную часть центрального городского могильника Азака (№ 3 по А.Н. Масловскому). Первое надгробие (рис. 2: 3) было найдено в заполнении ордынской хозяйственной ямы XIV в. Вертикальная стела прямоугольной формы изготовлена из желто-серого ракушечника, верхняя часть утрачена. Высота сохранившейся части 83,0 см, ширина - 46,8 см, толщина - 14,1 см. Основание плиты, вкапываемое в землю, прямоугольной формы толщиной 16,9 см. Стела тщательно обработана, с ровными гранями. На обе стороны плиты нанесен врезной орнамент тонкими глубокими линиями. На одной стороне нанесено изображение двух высоких симметрично поставленных свечей в высоких биконических поддонах. На обратной стороне в центральной части поля нанесено схематичное изображение подвешенной на двух цепях лампады с коническим поддоном и округлым туловом. На обеих сторонах плиты по краю прочерчены тонкие врезные линии в виде бордюра. Второй фрагмент надгробия XIV века происходил из переотложенного культурного слоя XVII-XVIII вв., изготовлен из желто-серого ракушечника (рис. 4: 1). От стелы сохранилось только навершие размерами $18,0 \times 14,2 \times 11,2$ см в виде пятилопастной (?) арки, от которой сохранилось только 2 лопасти и небольшая часть третьей лопасти. Плита тщательно обтесана, грани ровные, со следами воздействия огня. По внешнему краю плиты на обеих сторонах нанесен невысокий бордюр с помощью выборки фона. Стилизованный орнамент в виде растительных побегов и фрагмента пальметты выполнен на обеих сторонах камня с помощью выборки фона в невысоком рельефе.

На раскопе I по Петровскому бульвару, $38-22$, в 2019 году в заполнении современной водопроводной траншеи был найден фрагмент каменного надгробия XIV в. Камень происходил из поврежденного траншеей крупного каменного наземного сооружения - вероятно, мечети, вокруг которой располагался грунтовый могильник. Вместе с фрагментом надгробия было найдено 3 крупных каменных блока - возможно, деталь портала. Надгробие изготовлено из светло-желтого обработанного ракушечника, вероятно, имело прямоугольную форму с пятилопастной аркой. От камня сохранилась вершина в виде трехлопастной арки с треугольным навершием размерами 29,5×7,0×9,0 см (рис. 5: 2). На обеих сторонах арки нанесен схематичный орнамент тонкими врезными, расходящимися от центра линиями. Судя по аналогиям старокрымских каменных надгробий, линии могут символизировать лучи, исходящие от подвешенной горящей лампады.

На раскопе I по Петровскому бульвару, 20, в заполнении ордынской землянки XIV века (жилище 14) был найден фрагмент каменного надгробия размерами 41,0×39,0×12,0 cм, изготовленного из желто-серого ракушечника (рис. 4: 2). Вертикальная стела прямоугольной формы с трехлопастной аркой и килевидной вершиной, нижняя часть камня утрачена. На обе стороны плиты нанесен орнамент с помощью выборки фона в низком рельефе. На одной стороне изображена подвешенная на двух цепях горящая лампада с коническим горлом и округлым туловом, помещенная в михраб со стрельчатой аркой. На тулове лампы сохранились пятна красной краски. На противоположной стороне стелы в арке нанесены расходящиеся от центра врезные линии. В основном поле плиты нанесен геометрический орнамент в виде узла сложного плетения с ломаными широкими полосами. Геометрические плетенки, выстроенные из прямых перекрещенных под разными углами линий, стилизованные под изображение «звезды Давида», широко распространены как в ордынском Крыму, так и в других регионах средневекового Востока (Айбабина, 2016, с. 530). Найденное надгробие, вероятно, первоначально было установлено в погребении центрального городского могильника, располагавшемся в непосредственной близости от раскопа, и, судя по найденному керамическому материалу в заполнении землянки, может датироваться не позднее второй половины XIV века.

На раскопе по ул. Толстого, 20, в 2019 году было найдено два фрагмента каменных надгробий XIV века. Оба фрагмента происходят из центрального городского могильника Азака (№ 3 по А.Н. Масловскому), изготовлены из светло-желтого ракушечника, с тщательно обтесанными и зашлифованными сторонами. От первого надгробия сохранился небольшой фрагмент размерами 25,5×7,3×14,0 см. Плита сильно повреждена и выщерблена, орнамент утрачен, сохранилась только одна грань камня (рис. 4: 3). Особый интерес представляет второе надгробие. Вертикальная стела прямо- 

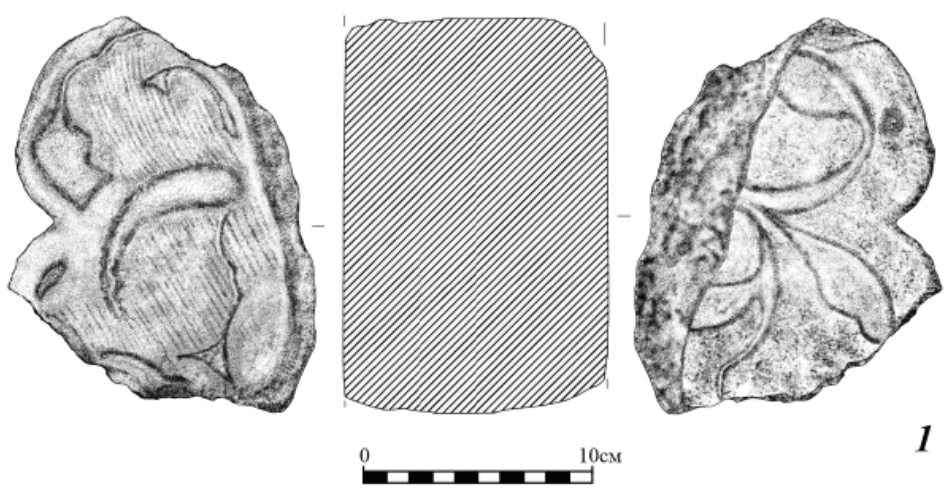

1
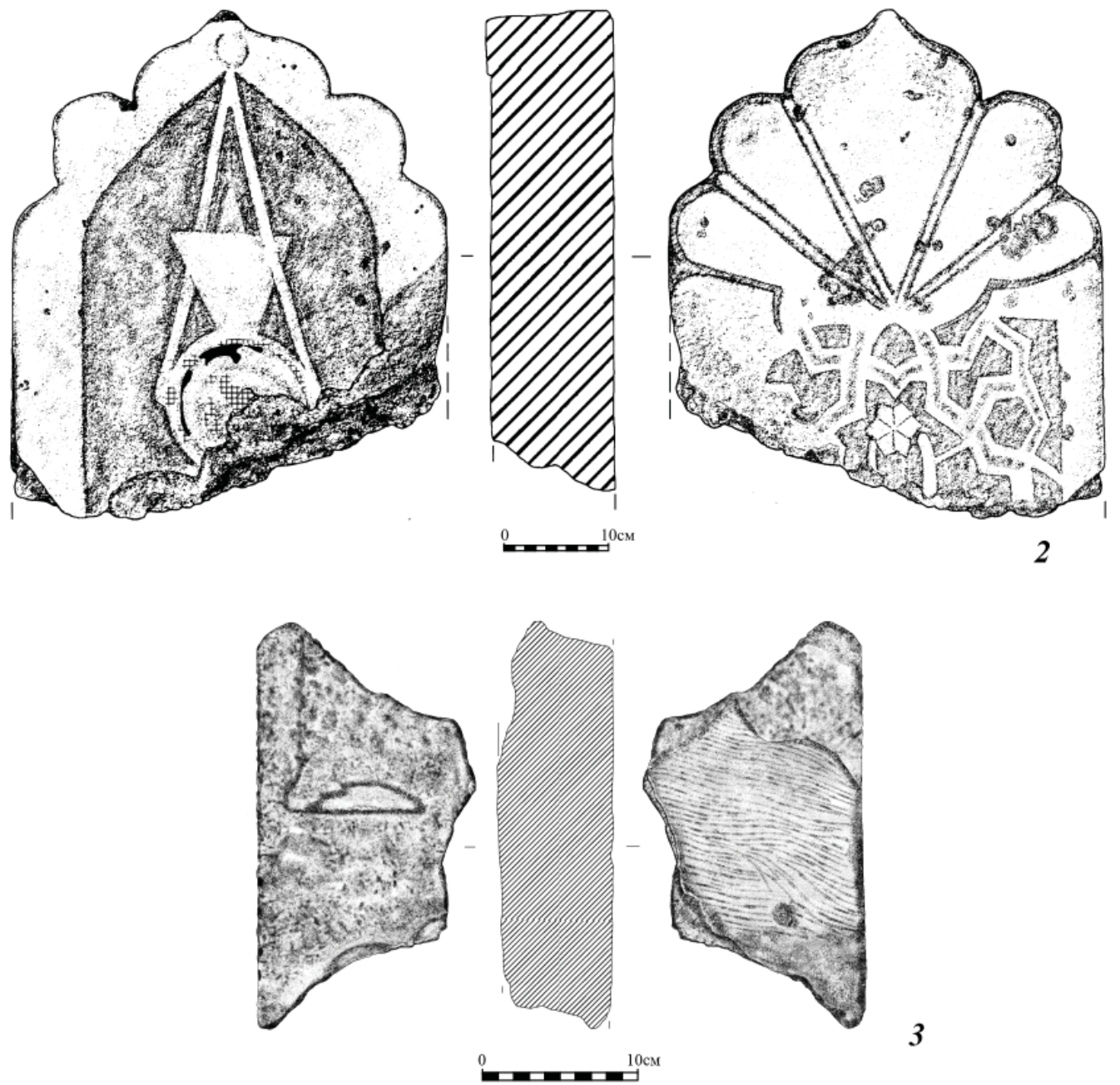

Рис. 4. Каменные надгробия из Азака: 1 - раскоп по ул. Ленина, 5 (2018 г.), 2 - раскоп по Петровскому бульвару, 20 (2019 г.), 3 - Раскоп по ул. Толстого, 20 (2020 г.)

Fig. 4. Stone-made gravestones from the city of Azak: 1 - excavation on the Lenina st., 5 (2018), 2 - excavation on the Petrovski boulevard, 20 (2019), 3 -excavation on the Tolstogo st., 20 (2020)

угольной формы, размерами 74,0×37,2×7,1 см, с пятилопастной аркой и треугольной вершиной (рис. 5: 1). На одной стороне плиты нанесено изображение горящей лампады с округлым туловом, коническим горлом и поддоном, подвешенной на стилизованно показанной пальметте. Орнамент выполнен глубокими четкими врезными линиями. На тулове лампы изображена восьмилепестковая розетка с овальными листками, вершины которых соединены дуговидными линиями таким образом, что создается образ шестилепестковой розетки с треугольными листками. Обращает внимание нарушение пропорций размеров лампы, которая в несколько раз больше подвешенных к ней цепей. Вероятно, мастер- 

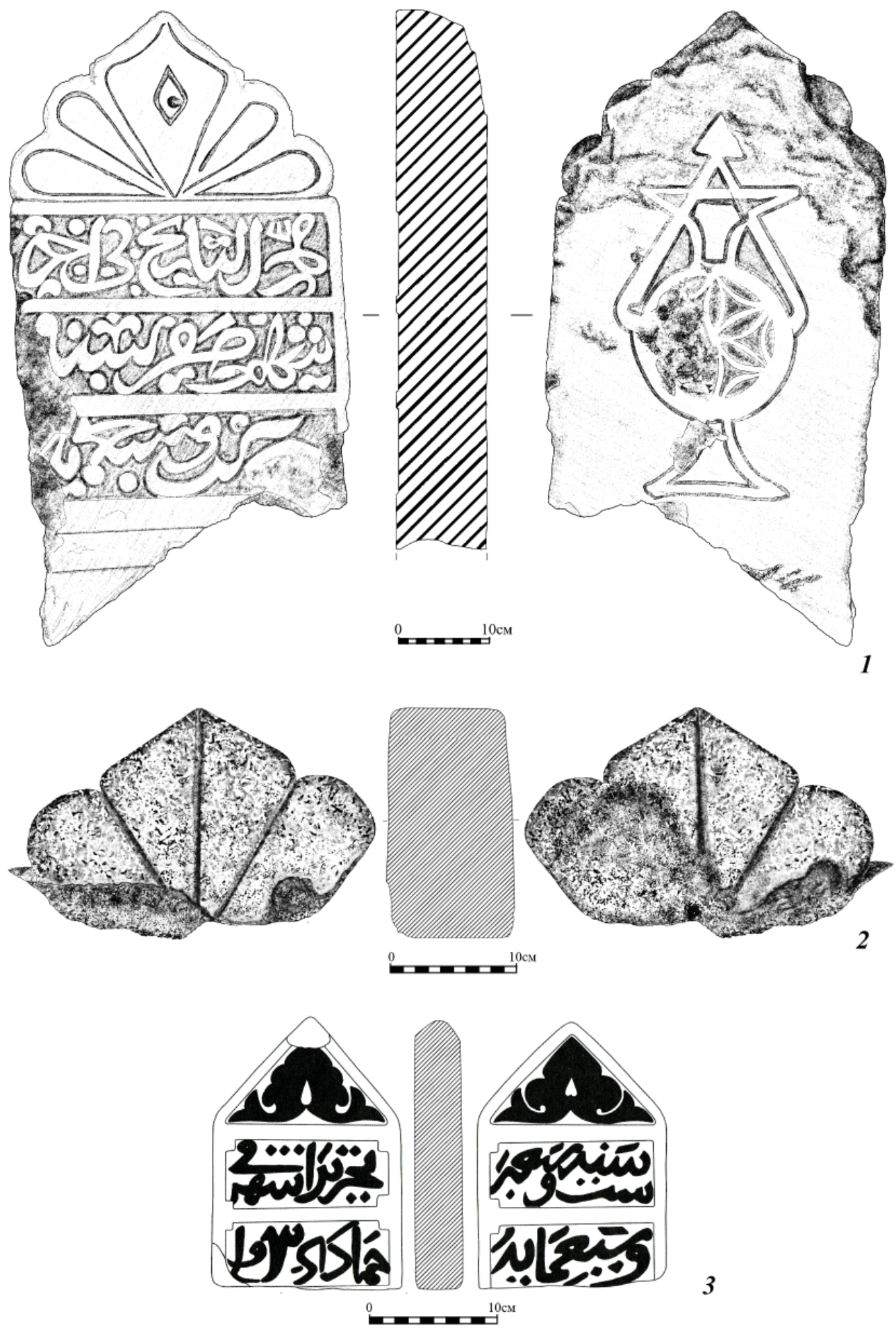

Рис. 5. Каменные надгробия из Азака: 1 - раскоп по ул. Толстого, 20 (2020 г.), 2 - раскоп по Петровскому бульвару, 38-22 (2019 г.), 3 - Севастопольская, 84. Сборы (1984 г.)

Fig. 5. Stone-made gravestones from the city of Azak: 1 - excavation on the Tolstogo st., 20 (2020), 2 - excavation on the Petrovski boulevard, 38-22 (2019), 3 - excavation on the Sevastopolskaya st., 84. Artefactual remains gathering (1984).

камнерез при составлении композиции первоначально вырезал изображение лампады, а уже в дальнейшем подвешенных цепей, которые не вместились в размеры камня, оказавшиеся значительно короче, чем должны быть (по аналогиям со старокрымских надгробий). На лицевой стороне стелы в арке глубокими врезными линиями нанесена пятилепестко- вая розетка, где четыре листка - овальные, а пятый, самый верхний - в виде ромбовидной фигуры с килевидным верхом, внутри которой вписан ромб. Основное поле плиты разделено на три прямоугольника невысокими бордюрами. По контуру плиты вырезан невысокий бортик. В каждом прямоугольнике нанесены эпиграфические надписи арабскими буквами 
почерком рельефный сульс с помощью выборки фона в низком рельефе. Текст состоит из

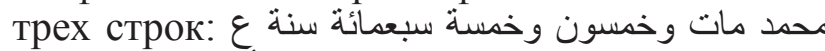

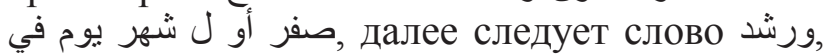
которое, вероятнее всего, следует переводить как «пастырь» или «наставник» (перевод Н.И. Юдина). Текст в переводе на русский гласит: «В день первый месяца Сафара года семьсот и пятьдесят пятого умер Мохаммед...» (перевод Н.И. Юдина). Трудность в переводе последнего слова связана с утратой части строки на надгробии. Дата первого числа Сафара 755 года хиджры соответствует 4 марта 1354 г. Уникальность найденной стелы состоит в том, что, помимо богатого орнаментального декора, это первое надгробие, найденное при раскопках золотоордынского Азака, на котором почти полностью сохранилась эпиграфия с указанием имени, даты смерти и, вероятно, рода деятельности умершего.

Изучение каменного архитектурного декоpa, в том числе и каменных надгробий, позволяет определить различные аспекты жизни средневекового восточного города, каким являлся золотоордынский Азак. Исследование орнаментальных и эпиграфических мотивов помогает выявить миграционные связи Азака с остальными центрами Золотой Орды и их влияние на культуру самого города. Архитектурное оформление и орнаментальные мотивы азакских надгробных памятников указывают на преобладающее влияние камнерезной культовой архитектуры Крыма и Малой Азии. Но в отличие от богато орнаментированных малоазийских памятников, азакские надгробия в большинстве оформлены схематично, без проработки мельчайших деталей, что указывает на тесную связь с художникамикамнерезами из золотоордынского Крыма, которые, переняв сельджукские традиции еще в XIII веке, заметно их упростили. Орнаментальные сюжеты и эпиграфия, характерные для других центров Золотой Орды (таких как Болгар и среднеазиатские городские центры), в Азаке не получили столь широкого распространения.

\section{ЛИТЕРАТУРА}

Айбабина Е.А. Декоративная каменная резьба Каффы XIV-XVIII вв. Симферополь: COHАT, 2001. $280 \mathrm{c}$.

Айбабина Е.А. Мусульманская каменная резьба Крыма // МИРАС-НАСЛЕДИЕ. Татарстан - Крым. Город Болгар и изучение татарской культуры в Татарстане и в Крыму в 1923-1929 годах: в 3-х томах. Т. 1. / сост. и отв. ред. С.Г. Бочаров, А.Г. Ситдиков. Казань: ООО «Астер Плюс», 2016. С. 510-543.

Акчокракль О. Старо-Крымские и Отузские надписи XIII-XV вв. // Известия Таврического общества истории, археологии и этнографии (ИТОИАЭ) / Отв. ред. Н.Л. Эрнст. Симферополь, 1927. Т. 1 (58). C. 5-17.

Акчокракль О. Старо-Крымские надписи XIII-XV вв. (По раскопкам 1928 г.) // Известия Таврического общества истории, археологии и этнографии (ИТОИАЭ) / Отв. ред. Н.Л. Эрнст. Симферополь, 1929. T. 3 (60). C. $152-159$.

Васильев Д.В. Ислам в Золотой Орде. Историко-археологическое исследование. Астрахань: ИД «Астраханский университет», 2007. 192 с.

Волков И.В. Надгробие золотоордынского времени из Новочеркасского музея // Историко-археологические исследования в Азове и на Нижнем Дону в 2006 г. Вып. 23. / Отв. ред. В.Я. Кияшко. Азов: Азовский музей заповедник, 2008. С. 478-496.

Волков И.В. Заметки по мусульманской эпиграфике в Ростовской области // Историко-археологические исследования в Азове и на Нижнем Дону в 2015-2016 гг. Вып. 30. / Отв. ред. В.Я. Кияшко. Азов: Азовский музей заповедник, 2018. С. 379-398.

Волков И.В. Эпиграфика Маджара // Археология Евразийских степей. 2018. №5. С. 38-42.

Гудименко И.В. Перевозчиков В.И. Работы І Азовского археологического отряда в 1988 г. // Историко-археологические исследования в г. Азове и на Нижнем Дону в 1988 г. Вып. 9. / Отв. ред. В.Я. Кияшко. Азов: Азовский музей заповедник, 1989. С. 14-16.

Гудименко И.В. Спасательные археологические раскопки в городе Азове и Азовском районе // Историко-археологические исследования в Азове и на Нижнем Дону в 1994 г. Вып 14. / Отв. ред. В.Я. Кияшко. Азов: Азовский краеведческий музей, 1997. С. 73-77.

Кравченко С.А. Археологические исследования в г. Азове и Азовском районе в 2015 г. // Историко-археологические исследования в Азове и на Нижнем Дону в 2015-2016 гг. Вып. 30. / Отв. ред. В.Я. Кияшко. Азов: Азовский краеведческий музей, 2018. С. 122-178.

Маммаев М.M. Надмогильные памятники детских погребений XIV-XV вв. из с. Кубачи: особенности декоративной отделки // История, археология и этнография Кавказа. 2019. Т. 15. № 4. С. 704-722. 
Масловский А.Н. Археологические исследования в городе Азове и Азовском районе в 2007-2008 годах // Историко-археологические исследования в Азове и на Нижнем Дону в 2007-2008 гг. Вып. 24. / Отв. ред. В.Я. Кияшко. Азов: Азовский краеведческий музей, 2010. С. 182-242.

Масловский А.Н. Топография городских могильников золотоордынского Азака и их влияние на общегородскую планировку // Генуэзская Газария и Золотая Орда. Т. 2. / Ред. С.Г. Бочаров, А.Г. Ситдиков. Кишинев: Stratum Plus, 2019. С. 641-656.

Масловский А.Н. Могильники Азака. История изучения и задачи будущих исследований // Историко-археологические исследования в Азове и на Нижнем Дону в 2015-2016 гг. Вып. 30. / Отв. ред. В.Я. Кияшко. Азов: Азовский краеведческий музей, 2018. С. 318-357.

Мухаметиин Д.Г. Татарские эпиграфические памятники. Региональные особенности и этнокультурные варианты / Археология евразийских степей. Вып. 6. Казань: Институт истории им. Ш. Марджани АН РТ, 2008. $131 \mathrm{c.}$

Пигарёв E.M., Тимофеев А.А. Мусульманские надгробия эпохи Золотой Орды (из фондов Астраханского музея-заповедника) // Астраханские краеведческие чтения: сборник статей. Вып. X / Ред. А.А. Курапов, Е.И. Герасимиди, А.Н. Алиева. Астрахань: Изд-во Сорокин Роман Васильевич, 2018. С. 68-71.

Усеинов Д.А. Мусульманские эпиграфические памятники Старого Крыма (XIII-XIV вв.) // Золотоордынское наследие: Материалы VI Международного Золотоордынского Форума «Рax Tatarica: генезис и наследие государственности Золотой Орды», Казань, 26-28 июня 2019 г. Вып. 3. Казань: Институт истории им. Ш. Марджани АН РТ, 2019. С. 87-95.

Шихсаидов А.Р. Эпиграфические памятники Дагестана X-XVII вв. как исторический источник. М.: Наука, 1984. 463 с.

Якобсон А.Л. Крым в Средние века. М.: Наука, 1973. 170 с.

H. Kamil Bicici. Patterned Lamp and Candlestick Gravestones in Iznik Museum // Turkish Studies - International Periodical For The Languages, Literature and History of Turkish or Turkic. Ankara, 2012. Volume 7/3. S. 637-661.

\section{Информация об авторах:}

Минаев Александр Павлович, старший научный сотрудник, Азовский историко-археологический и палеонтологический музей-заповедник (г. Азов, Россия); alexminaev1987@gmail.com

Юдин Никита Игоревич, научный сотрудник, Азовский историко-археологический и палеонтологический музей-заповедник (г. Азов, Россия); aniarchaeologist@gmail.com

\section{REFERENCES}

Aibabina, E. A. 2001. Dekorativnaia kamennaia rez'ba Kaffy (XIV-XVIII vv.) (Ornamental Stone Carving of Kaffa in the 14 $14^{\text {th }} 18^{\text {th }}$ Centuries). Simferopol: "Sonat" Publ. (in Russian).

Aibabina, E. A. 2016. In Bocharov, S. G., Sitdikov, A.G. (eds.). MIRAS-NASLEDIE. Tatarstan - Krym. Gorod Bolgar i izuchenie tatarskoj kul'tury v Tatarstane i v Krymu v 1923-1929 godah: v 3-kh tomah (MIRAS-NASLEDIE. Tatarstan and Crimea. The City of Bolgar and the study of Tatar culture in Tatarstan and the Crimea in 1923-1929: in 3 volumes). 1. Kazan: "Aster Plyus" Publ., 510-543 (in Russian).

Akchokrakly, O.1927. In Ernst, N. L. (ed.). Izvestiya Tavricheskogo obshchestva istorii, arkheologii $i$ etnografii (Proceedings of the Taurida Society for History, Archaeology, and Ethnograph) 1(58). Simferopol. 152-159 (in Russian).

Akchokrakly, O. 1929. In Ernst, N. L. (ed.). Izvestiya Tavricheskogo obshhestva istorii, arkheologii $i$ etnografii (Proceedings of the Taurida Society for History, Archaeology, and Ethnograph) 3(60). Simferopol. 152-159 (in Russian).

Vasil'ev, D. V. 2007. Islam v Zolotoi Orde: Istoriko-arkheologicheskoe issledovanie (Islam in the Golden Horde: Historical-Archaeological Research). Astrakhan: "Astrakhanskii universitet" Publishing House (in Russian).

Volkov, I. V. 2008. In Kiiashko, V. Ya. (ed.). Istoriko-arkheologicheskie issledovaniia v Azove i na Nizhnem Donu (Historical and Archaeological Research in Azov and Lower Don Region) 23. Azov: Azov HistoricalArchaeological and Palaeontological Museum-Reserve, 478-496 (in Russian).

Volkov, I. V. 2018. In Kiiashko, V. Ya. (ed.). Istoriko-arkheologicheskie issledovaniia v Azove i na Nizhnem Donu (Historical and Archaeological Research in Azov and Lower Don Region) 30. Azov: Azov HistoricalArchaeological and Palaeontological Museum-Reserve, 379-398 (in Russian).

Volkov, I. V. 2018. In Arkheologiia Evraziiskikh stepei (Archaeology of Eurasian Steppes) 5. 38-42 (in Russian). 
Gudimenko, I. V. Perevozchikov, V. I. 1989. In Kiiashko, V. Ya. (ed.). Istoriko-arkheologicheskie issledovaniia v Azove i na Nizhnem Donu (Historical and Archaeological Research in Azov and Lower Don Region) 9. Azov: Azov Historical-Archaeological and Palaeontological Museum-Reserve, 14-16 (in Russian).

Gudimenko, I. V. 1997. In Kiiashko, V. Ya. (ed.). Istoriko-arkheologicheskie issledovaniia v Azove i na Nizhnem Donu (Historical and Archaeological Research in Azov and Lower Don Region) 14. Azov: Azov Historical-Archaeological and Palaeontological Museum-Reserve, 73-77 (in Russian).

Kravchenko, S. A. 2018. In Kiiashko, V. Ya. (ed.). Istoriko-arkheologicheskie issledovaniia v Azove i na Nizhnem Donu (Historical and Archaeological Research in Azov and Lower Don Region) 30. Azov: Azov Historical-Archaeological and Palaeontological Museum-Reserve, 122-178 (in Russian).

Mammaev, M. M. 2019. In Istoriia, arkheologiia i etnografia Kavkaza (History, Archaeology and Ethnography of the Caucasus) 15 (4), 704-722 (in Russian).

Maslovsky, A. N. 2010. In Kiiashko, V. Ya. (ed.). Istoriko-arkheologicheskie issledovaniia v Azove i na Nizhnem Donu (Historical and Archaeological Research in Azov and Lower Don Region) 24. Azov: Azov Historical-Archaeological and Palaeontological Museum-Reserve, 182-242 (in Russian).

Maslovsky, A. N. 2019. In Bocharov, S. G., Sitdikov, A. G. (ed.). Genuezskaia Gazariia i Zolotaia Orda (The Genoese Gazaria and the Golden Horde) 2. Series: Archaeological Records of Eastern Europe. Kazan; Kishinev: "Stratum Plus" Publ., 641-656 (in Russian).

Maslovsky, A. N. 2018. In Kiiashko, V. Ya. (ed.). Istoriko-arkheologicheskie issledovaniia v Azove i na Nizhnem Donu (Historical and Archaeological Research in Azov and Lower Don Region) 30. Azov: Azov Historical-Archaeological and Palaeontological Museum-Reserve, 318-357 (in Russian).

Muhametshin, D. G. 2008. Tatarskie epigraficheskie pamiatniki. Regional'nye osobennosti i etnokul'turnye variant (Tatar epigraphic sites. Regional features and ethnocultural versions). Series: Arkheologiia Evraziiskikh stepei (Archaeology of the Eurasian steppes) 6. Kazan: Institute of History named after Sh. Mardzhani, Tatarstan Academy of Sciences Publ. (in Russian).

Pigarev, E. M., Timofeev, A. A. 2018. In Kurapov A.A, Gerasimidi, E. I., Alieva, A. N. (eds.). Astrakhanskie kraevedcheskie chteniia (Astrakhan Readings of Local History) X. Astrakhan: "Sorokin R.V." Publ., 68-71 (in Russian).

Useinov, D. A. 2019. In Mirgaleev, I. M. (ed.). Zolotoordynskoe nasledie: Materialy VI Mezhdunarodnoi nauchnoi foruma "Pax Tatarica: genezis i nasledie gosudarstvennosti Zolotoi Ordy", Kazan, 26 - 28 iiunia $2019 \mathrm{~g}$ (Heritage of the Golden Horde: Proceedings of the International Scientific Forum "Pax Tatarica: Genesis and Legacy of the Golden Horde Statehood", Kazan, June 26-28, 2019.) 3. Kazan: Institute of History named after Sh. Mardzhani, Tatarstan Academy of Sciences Publ., 87-95 (in Russian).

Shihsaidov, A. R., 1984. Epigraficheskie pamiatniki Dagestana X-XVII vv. kak istoricheskii istochnik (Epigraphic Monuments of Dagestan of the 10 ${ }^{\text {th }}-17$ th Centuries as a Historical Source). Moscow: "Nauka" Publ. (in Russian).

Yakobson, A. L. 1973. Krym v Srednie veka (Crimea in the Middle Ages). Moscow: "Nauka" Publ. (in Russian).

H. Kamil Bicici. 2012. In Turkish Studies - International Periodical For The Languages, Literature and History of Turkish or Turkic. 7(3). Ankara, 637-661 (in English).

About the Authors:

Minaev Alexander P. Azov History, Archaeology and Paleontology Museum-Reserve. Moskovskaya St., 38/40, Azov, 346780, Russian Federation; vallet-dre@mail.ru

Iudin Nikita I. Azov History, Archaeology and Paleontology Museum-Reserve. Moskovskaya St., 38/40, Azov, 346780, Russian Federation; niarchaeologist@gmail.com

Статья поступила в журнал 01.04.2021 г.

Статья принята к публикации 01.04.2021 г. Авторы внесли равноценный вклад в работу. 